\title{
О РОЛИ ДАЙКОВЫХ И ЖИЛЬНЫХ ТЕЛ В РАСПРЕДЕЛЕНИИ CU-Ni-PGE МИНЕРАЛИЗАЦИИ В МОНЧЕГОРСКОМ РАССЛОЕННОМ КОМПЛЕКСЕ (КОЛЬСКИЙ ПОЛУОСТРОВ, РОССИЯ)
}

\author{
П. В. Припачкин \\ Геологический институт Кольского научного центра РАН, г. Апатиты \\ Поступила в редакцию 6 апреля 2018 г.
}

\begin{abstract}
Аннотация: приводится краткий обзор роли дайковых и жильных тел в составе дифференцированных интрузий для концентрации $\mathrm{Cu}-\mathrm{Ni}$-PGE минерализацчии. В результате наших исследований в пределах Мончегорского расслоенного ультрамафит-мафитового комплекса Кольского полуострова установлено, что минерализация Южносопчинского расслоенного массива, связана не с расслоенной серией пород (пироксениты, нориты, габбронориты), а с жильными телами магнетит-амфибол-плагиоклазового состава в пироксенитах краевой серии. Предполагается также, что перспективное PGE оруденение зоны сочленения Мончеплутона и Мончетундровской интрузии относится не к рифовому, а к контактному типу, переотложенному в ходе позднемагматического жилообразования. Учитывая данные исследований геологов ОАО «Центрально-Кольская экспедиция» о новом типе жильной Си-PGE минерализации на участке Западный Ниттис, делается вывод о важности данного типа оруденения (наряду с рифовым) в общем балансе Мончегорского комплекса.
\end{abstract}

Ключевые слова: дифференцированныле интрузии, дайки, жиль, Cu-Ni-PGE минерализаџия, Кольский полуостров, Мончегорский комплекс.

\section{ON THE ROLE OF DYKE AND VEIN BODIES IN THE DISTRIBUTION OF Cu-Ni-PGE MINERALIZATION IN THE MONCHEGORSK LAYERED COMPLEX (KOLA PENINSULA, RUSSIA)}

\begin{abstract}
: a brief review of the role of dyke and vein bodies from the differentiated intrusions for the concentration of Cu-Ni-PGE mineralization is given. Our research within the Monchegorsk layered ultramafic-mafic complex of the Kola Peninsula has established that the mineralization of the Southsopchinsky layered massif is not connected with it "layered unit" (pyroxenite, norite, gabbronorites). The vein bodies of magnetite-amphibole-plagioclase composition are located in pyroxenite of "margin unit". It is also assumed that the prospective PGE mineralization in the contact zone of Monchepluton and Monchetundra intrusion does not refer to the "reef-type". We believe that mineralization belongs to the "contact-type" redeposited during the late-magmatic processes. According to findings of geologists of JSC "Central Kola Expedition" a new type of vein Cu-PGE mineralization in the West Nittis target, the conclusion about the importance of this type of mineralization (along with a "reef-type") in the overall balance of the Monchegorsk complex is given.
\end{abstract}

Keywords: differentiated intrusions, dykes, veins, Cu-Ni-PGE mineralization, Kola Peninsula, Monchegorsk complex.

\section{Введение}

Дайковые и жильные тела широко развиты в пределах интрузивных дифференцированных комплексов различного состава и возраста. Обычно подобные образования (в особенности жилы) связаны с заключительными или постмагматическими стадиями формирования интрузий, возможно, поэтому их характеристике зачастую не уделяют достаточного внимания. Однако исключения делаются в тех случаях, когда такие объекты вносят заметный вклад в концентрацию и/или перераспределение рудного вещества.
Особое место здесь занимают так называемые «рудные жилы», с которыми в ряде случаев преимущественно связана рудная минерализация.

В соответствии с конъюнктурой рынка или исчерпанием запасов, в Мончегорском рудном районе считались перспективными различные типы руд, локализованные в пределах Мончегорского раннепротерозойского мафит-ультрамафитового комплекса (Кольский регион, Россия). Сначала и это послужило причиной строительства в 30-е годы XX века комбината «Североникель», в качестве главного промышленного 
типа выступали богатые сульфидные медно-никелевые руды, в основном жильного типа. К 1971 году их запасы были существенно истощены и комбинат перешел на обогащение Норильских (перевозимых Северным морским путем) и Печенгских медно-никелевых руд. В 1990-е годы были начаты вскрышные работы и получена первая руда в пределах Сопчеозерского стратиформного хромитового месторождения. Однако вскоре отработка этих руд компанией «Норильский никель» была признана нерентабельной, а хромитовый карьер был законсервирован. В конце 1990-х - начале 2000-х годов в пределах Мончегорского комплекса был выделен малосульфидный платино-палладиевый («рифовый») тип оруденения с постановкой ряда месторождений на государственный баланс, но из-за изменения конъюнктуры рынка разработка месторождений не была начата. Тем не менее, данный тип руд считается сегодня наиболее промышленно важным для Мончегорского комплекса. В то же время, относительно недавние исследования различных типов Cu-PGE (platinum group elements - элементы платиновой группы) и PGE оруденения, связанного с породами дайково-жильного комплекса, заставляют вернуться к переоценке перспектив такого типа рудной минерализации, и, в частности, попытаться ответить на вопрос - насколько важным он является в общем балансе руд Мончегорских интрузий.

\section{Краткий обзор проблемы}

Как отмечают в своей работе Н. М. Чернышев и М. Н. Чернышева, «дайковые образования, являющиеся одним из существенных элементов магматических и рудно-магматических систем (РМС), представляют исключительный интерес для решения фундаментальных проблем геологии, геодинамики, петрологии и рудообразования. В подобных РМС дайковые образования являются не только важнейшим структурновещественным, но и рудонесущим компонентом. Эта особенность наиболее отчетливо прослеживается в сульфидных платиноидно-медно-никелевых РМС» [1 стр.109-110]. В достаточно обширной сводке этих авторов приводятся примеры рудоносных даек из разнообразных геологических обстановок (петрологогенетических типов), с различными объемами и качеством Cu-Ni-PGE минерализации. Ниже мы, взяв на вооружение данный принцип, приведем несколько наиболее характерных примеров таких дайковожильных образований (тел).

\section{Дайковые и жильные тела как подводящие каналь}

В архейском куполе Камбалда (Западная Австралия) с силлами и дайкообразными телами, рассматриваемыми в качестве подводящих каналов коматиитового расплава, связаны сульфидные месторождения в основании лавовых потоков. Руды характеризуются высокими содержаниями $\mathrm{Ni}$ (до 14 $\%), \mathrm{Cu}(1,16 \%), \mathrm{Pt}(1,4-1,8$ г/т), Pd (1,61-2,2 г/т). Эруптивные центры, сопровождающиеся сульфидным оруденением, рассматриваются как лавовые каналы и в областях раннепротерозойского магматизма Канады $[1,2]$.

На месторождении Грейт Лейкс Никел (озеро Верхнее, Онтарио, США), сульфидные платиноидномедно-никелевые руды в дифференцированных габброидных породах (нориты, анортозиты, оливиновые нориты, пегматоидные габбро) соединены с дайкой рудоносных пикритов, рассматриваемой в качестве магматического проводника подобно минерализованным питающим дайкам Норильского района России. Так, медно-никелевая минерализация установлена во многих габбро-долеритовых дайках Центрального Таймыра [1 и ссылки там].

Одним из примеров дайкообразных тел как магматических рудонесущих каналов является нижнепротерозойское месторождение Войсис Бэй (Лабрадор, Канада), в котором несколько рудных зон с сульфидным PGE-Cu-Ni минерализацией непосредственно связаны с питающим источником [1, 3]. С дайковым телом связано также позднерифейское месторождение Джинчуан (Китай), являющееся третьим в мире (после Норильского района и Садбери) по запасам Ni и $\mathrm{Cu}[1,4]$.

\section{Дайковые и жильные тела}

в магматических камерах расслоенных интрузий

В расслоенном мафит-ультрамафитовом позднеархейском комплексе Стиллуотер (Монтана, США) породы пересекаются кварцевыми монцонитами, имеющими возраст, близкий возрасту мафитовых пород, а также мафитовыми дайками близкого и более молодого возраста. Среди одного из типов сульфидного и PGE оруденения выделяются, в том числе пегматоидные линзы, трубки и другие секущие оруденелые тела (аналоги дунитовых трубок Бушвельда) [2 и ссылки там].

В другом позднеархейском дифференцированном ультрамафит-мафитовом комплексе Лак дес Ил (Канада, Онтарио) широко распространены секущие тела такситовых габбро, переходящие в пегматоидные лейкогаббро, которые в свою очередь пересекаются жилами габбровых пегматитов. Рудоносная зона Роби локализована, главным образом, в такситовых габбро, но наиболее высокие концентрации PGE и Аu связаны с жильными телами габбровых пегматитов (до 35 г/т $\mathrm{PGE}+\mathrm{Au})[1,2]$.

Сульфидоносные жилы также развиты в пределах расслоенного интрузивного комплекса Каничи, который является самым большим из мафитультрамафических тел в фельзитовых и мафических метавулканических породах в северной части архейского зеленокаменного пояса Тунагами (Онтарио, Канада). Ультраосновный апофиз вдоль северного фланга интрузии содержит минерализованную зону вкрапленного и жильного пирротина, халькопирита и пентландита. Наиболее распространенным сульфидом в породах жильного комплекса является халькопирит. Джеймс и Хоук считают, что минерализация жил представляет собой ремобилизированные магматиче- 
ские сульфиды, ранее существовавшие в оливиновом перидотите [5]. Значения $\mathrm{Cu}$ и $\mathrm{Ni}$ в жилах достигают $12 \%$; содержания $\mathrm{Pt}, \mathrm{Pd}$ и $\mathrm{Au}$ в среднем составляют 2,$1 ; 9,02$ и 2,1 г/т, соответственно [3].

В одном из крупнейших в мире многофазном мафит-ультрамафитовом дифференцированном нижнепротерозойском Комплексе Бушвельд (ЮАР) расслоенная серия Ростенбург сопровождается разнообразными по составу рудонесущими силлами, дайками и вертикальными пегматоидными трубками (дунитовые и гортонолитовые платиноносные трубки Онвервах, Мооихек, Дрископ, никеленосные сульфидосодержащие бронзититовые трубки типа Твифонтейн и др.). Взгляды на генезис этих тел варьируют от метасоматического до магматического и флюидно-магматического в виде неоднократных иньекций во время образования массива [1 и ссылки там].

В пределах раннепротерозойской интрузии Кейвица (Финляндия), состоящей из оливиновых пироксенитов, пироксенитов и габбро, часто встречаются ксенолиты вмещающих осадочных и вулканогенноосадочных пород, а также многочисленные дайки и жилы [6]. Среди них наиболее промышленно важными являются жилы массивных сульфидов. Иногда они образуют сложно ветвящиеся штокверки или зоны брекчии. По составу жилы массивных сульфидов относятся к так называемому «ложному» или «неправильному» рудному типу, бедному $\mathrm{Ni}$, но обогащенному $\mathrm{Cu}$. Содержание $\mathrm{Pt}$ не превышает 0,04 г/т. T. Мутонен полагает, что сульфидные жилы так называемого «ложного» типа (бедные $\mathrm{Ni}$ ), образовались из маловязкой интерстициальной сульфидной жидкости, которая просачивалась вниз в трещины сжатия из вышележащей кристаллической каши, содержащей сульфидную жидкость [6].

В пределах Еланского месторождения ЕланьВязовского раннепротерозойского дунит-перидотитпироксенит-габброноритового интрузива (Воронежский кристаллический массив, Россия), установлено богатое по содержанию цветных и благородных металлов оруденение, связанное с дайками и пегматоидами роговообманкового габбро, а также более позднее по времени формирования оруденение, ассоциирующее с завершающей диоритовой интрузивной фазой и ее жильными комагматами [1].

\section{Дайковые и жильные тела}

в концентрически-зональных массивах

В Кондерском дунит-клинопироксенитовом щелочно-ультраосновном зонально-кольцевом позднепротерозойском массиве (Алданский щит) наблюдается сульфидная (с PGE) минерализация, заключенная в щелочных метасоматитах и жилах. Предположительно, этот тип связан с ремобилизацией металлов под воздействием щелочных (карбонатно-хлориднонатровых) растворов. Для него характерно непостоянное содержание ЭПГ, изменчивость отношения $\mathrm{Pd} / \mathrm{Pt}$ (от 0,07 до 8 при среднем около 1) и небольшие (десятки сантиметров - первые метры) мощности рудных интервалов [7].

В пределах более молодого позднеордовикского концентрически-зонального Светлоборского пироксенит-дунитового массива (Средний Урал, Урало-Аляскинский тип), так называемая «платиноносная зона Высоцкого» (среднее содержание платины составляет около 1,5 г/т) связана с полосой даек пироксенитов, горнблендитов и иситов (местное название для мелкозернистой разновидности горнблендита), прорывающих консолидированные дуниты. В пределах данной полосы локализованы многочисленные жилы, содержащие хлорит, флогопит, антигорит. Зона в целом представляет собой линейный штокверк, выполненный гидротермально-метасоматическими образованиями. Рядом авторов высказано предположение о пневматолитово-гидротермальном происхождении платиновой минерализации, как всего Уральского платиноносного пояса, так и интрузивных комплексов Урало-Аляскинского типа других регионов [8].

\section{Дайковые и жильные тела во вмещзающих породах \\ В некоторых случаях, минерализованные дайки и} жилы интенсивно развиты во вмещающих магматические комплексы породах рамы. Одним из наиболее ярких примеров является раннепротерозойский импактный магматический комплекс Садбери (МКС) в Канаде. В нем выделяются рудоносные дайкоподобные тела, расположенные радиально, в некоторых случаях - концентрически к Главному телу МКС, так называемые «офсеты», сложенные кварцевыми диоритами [2]. Офсеты могут быть удалены от МКС во вмещающие породы на расстояние до 20 км. Средние содержания цветных и благородных металлов в месторождениях офсетов Садбери: $\mathrm{Ni}$ - до 6,5\%, $\mathrm{Cu}-$ до $12,8 \%, \mathrm{Pt}$ - до 13,8 г/т, $\mathrm{Pd}$ - до 15 г/т [1].

В пределах уже упоминавшегося позднепротерозойского месторождении Войсис Бэй (Лабрадор, Канада) в гнейсах экзоконтакта имеются богатые медью жилы с высоким содержанием халькопирита и борнита [2 и ссылки там].

В мафит-ультрамафитовом рифейском комплексе Игл (Северный Мичиган, США) встречаются четыре различных типа сульфидной минерализации. Помимо вкрапленных и массивных руд, здесь также развиты и сульфидные жилы в протерозойских осадочных породах. В богатых медью жилах содержатся различные количества халькопирита (25-100 \%), пирротина (1$50 \%)$ и пентландита (1-30\%), локальные участки содержат PGE минерализацию [9].

Дайковые и жильные тела

в краевых сериях расслоенных комплексов

Часто в расслоенных мафит-ультрамафитовых комплексах дайковые и жильные тела приурочены к так называемым «краевым сериям». Отличительными особенностями краевых серий являются, в том числе, развитие магматических (интрузивных) и эруптивных брекчий, пегматоидных жильных тел, а также так 
называемого «контактного оруденения». Брекчии широко развиты в различных расслоенных мафитультрамафитовых комплексах, таких как массив Рам (Шотландия), комплексы Дулут (США) и Бушвельд (ЮАР), интрузии Суханко-Контиярви (Финляндия), Федорова тундра (Россия) и др.

Контактное оруденение представляет собой относительно мощную зону минерализованных мафических пород вдоль базального контакта интрузии. В отличие от рудных зон рифового типа, едва ли ни единственным экономически важным контактным месторождением PGE является «Платриф» в комплексе Бушвельд (ЮАР) [10]. Тем не менее, фактически, большинство крупных расслоенных интрузий имеют минерализацию контактного типа с переменной мощностью и концентрацией металлов. К Cu-Ni-PGE месторождениям этого типа М.Л. Зентек относит так же, как и [10], «Платриф» Бушвельдского массива, финскую интрузию Пеникат, комплекс Дулут (США) и массив Федоровой Тундры (Россия) [11].

На сходство контактных зон месторождений финской интрузии Суханко-Контиярви (миксинг-зона) и Платриф-зоны Бушвельда указывают в своей работе М. Ильина и К. Ли [12]. В массиве Контиярви отмечается мощная зона брекчии, к которой приурочены дайки, развитые субпараллельно базальному контакту интрузии. Участки интенсивного брекчирования пород широко развиты в приконтактовых зонах канадских интрузий Ист Булл и Ривер Велли. [12]. Заметим, что подобная картина наблюдается и в пределах «Южносопчинского участка» зоны сочленения Мончеплутона и Мончетундровской интрузии [13], геология которой будет рассмотрена ниже при характеристике Мончегорского комплекса.

По мнению некоторых исследователей, интрузив Суханко-Контиярви является наиболее близким аналогом массива Федоровой тундры $[14,15]$. Главные черты сходства интрузий Суханко-Контиярви и Федорова тундра состоят в наличии в нижних частях их разрезов мощной эруптивной брекчии с обломками интрузивных пород, генетически связанных с интрузивами, а также в развитии платиноносной сульфидной вкрапленности и характерных неравномернозернистых (такситовых) структур в породах цемента брекчии.

По мнению Б. Кариковски и соавторов, ярким примером развития минерализации PGE-Ni-Cu контактного типа является Мончегорский раннепротерозойский расслоенный мафит-ультрамафитовый комплекс [10].

\section{Дайковые и жильные тела в связи с Cu-Ni-PGE минерализацией Мончегорского комплекса}

Мончегорский комплекс в Кольском регионе России (рис. 1, 2) относится к группе палеопротерозойских расслоенных массивов Фенноскандинавского щита, и включает в себя, по меньшей мере, две интру-

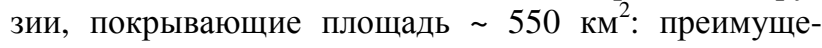
ственно ультрамафитовый Мончеплутон и преимущественно мафитовый массив Главного хребта $[16,17]$. В настоящей работе Мончегорским комплексом мы будем называть Мончеплутон и непосредственно примыкающую к нему часть Главного хребта - Мончетундровскую интрузию, поддерживая подобную трактовку некоторых авторов [18].

Породы дайкового комплекса в Мончегорском рудном районе можно разбить на две группы: дайки локального комплекса, пространственно и генетически связанные с интрузивными массивами Мончегорского комплекса - Мончеплутоном и Мончетундровской интрузией, и дайки региональных комплексов за пределами района. Основная часть даек первой группы имеет раннепротерозойский возраст и концентрируется в пределах крупной тектонической зоны на контакте вышеназванных массивов [19, 20]. Большинство даек не имеет зон закалок, что, видимо, обусловлено их внедрением в неостывшие интрузивные породы. Мощность дайковых тел варьирует от десятков сантиметров до десятков метров, максимально до 100 м.

Среди даек этой группы выделяются: гарризить (развитые в пределах Мончетундровской интрузии), крупно- и среднезернистые габбронориты, (прорывающие породы Мончеплутона), крупно- и среднезернистые магнетитовые габброиды (прорывающие дуниты Сопчеозерского хромитового месторождения), микрогаббро (залегающие на северо-восточном фланге Сопчеозерского месторождения), гранофиры, микрогранофиры и микрограниты, меланонорить и ортопироксениты (прорывающие породы Мончетундровской интрузии массива и, реже, Мончеплутона), пижонитовые и оливиновые микрогаббро [19].

Габбронориты, магнетитовые габброиды и микрогаббро отвечают IV дайковой фазе, а меланонориты II фазе образования пород Мончеплутна, выделенных Е. К. Козловым [21]. По данным [20] тела меланоноритов-ортопироксенитов внедрялись позже даек габброноритов, но раньше даек региональных комплексов. В целом, на основе геологических и геохронологических данных, в Мончегорском рудном районе устанавливается следующая последовательность внедрения магматических фаз: Мончеплутон - Мончетундровская интрузия - локальный комплекс - региональные дайковые комплексы. Последовательность характеризуется эволюцией состава материнских магм - от примитивных к более эволюционированным [19]. Самая ранняя фаза, предшествовавшая раскрытию магмоподводящей зоны Мончеплутона и подъему высокомагнезиальных расплавов, по-видимому, представлена телами низкокалиевых толеитов [20].

Значимой связи промышленного оруденения с дайками в пределах Мончегорского комплекса не отмечено. В ряде случаев они лишь ограничивают рудные залежи, как например, на юго-западном фланге Сопчеоозерского хромитового пласта [20]. Однако некоторые авторы относят к породам дайкового комплекса и диорит-пегматиты, в которые переходят рудные сульфидные жилы Мончеплутона, считая их (диорит-пегматиты) интрамагматическими (внутриинтрузивными) образованиями, возникающими за счёт обогащенного флюидами и металлами интер- 


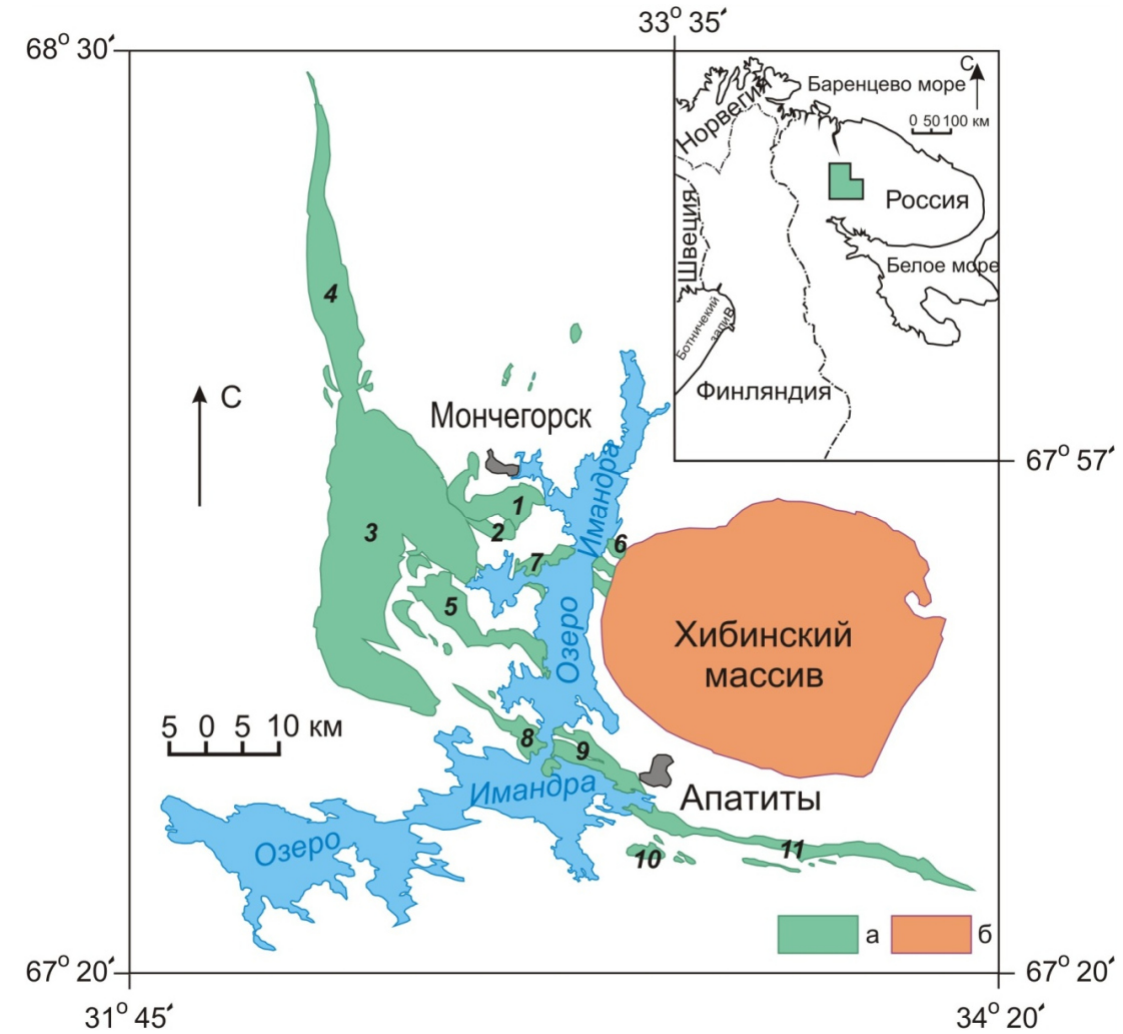

Puc. 1. Схема размещения главных мафит-ультрамафитовых расслоенных комплесков центральной части Кольского полуострова [13]: $a$ - Мафит-ультрамафитовые расслоенные комплексы: 1 - Мончеплутон, 2 - Южносопчинский массив; Расслоенный комплекс Главного хребта: 3 - Мончетундровская интрузия, 4 - Чуна-Волчьетундровкая интрузия; Имандровский лополит: 5 - массив Майявр-Девичья, 6-7 - массив Северный, 8-11-Умбареченский массив; $\sigma$ - Хибинский щелочной массив. кумулусного расплава [1]. Известны также отдельные случаи рудоносности даек в пределах субмеридиональной ветви Мончеплутона на участке Западный Ниттис. Как видно, в обоих последних случаях оруденение в дайках весьма тесно связано с жильными породами Мончегорского комплекса.

Интрузии Мончеплутона пересекаются жилами пегматитов основного и среднего состава, а также жильными телами богатых сульфидных руд, залегающими в пределах массивов Ниттис-КумужьяТравяная (НКТ) и горы Сопча. На горе Ниттис сульфидные жилы часто переходят на глубине в рудносиликатные пегматиты, отвечающие по составу норитам, габброноритам и диоритам [19 и ссылки там]. В пределах «Критического горизонта» массива Нюд выделяются жильные и гнездообразные тела пегматитов и рудных пегматитов основного состава, приуроченные как к контактам различных пород, так и выполняющие системы субвертикальных трещин. По мнению В.Ф. Смолькина, ранее горизонт представлял собою кровлю первичной магматической камеры. При внедрении новых порций расплава, материал бывшей кровли частично подвергся плавлению с образованием системы жил основного состава [19].

Необходимо отметить, что жильный тип минерализации Мончеплутона долгие годы определял его промышленный потенциал. На сегодняшний день, среди типов рудных тел Мончеплутона выделяют стратиформные хромитовые; жильные, инъекционные и вкрапленные (в том числе - донные) комплексные PGE-Cu-Ni и малосульфидные платино-палладиевые месторождения «рифового» типа [18]. Среди них пока наиболее интенсивно разрабатывались лишь объекты с комплексной PGE-Cu-Ni минерализацией, а среди них - именно месторождения жильных руд.

Напомним, что жильным породам Мончегорского комплекса не придавалось большого значения до тех пор, пока в 30-е годы прошлого века не были открыты уникальные для этого интрузива, богатые сульфидные жилы массивов НКТ и Сопча, которые были практически полностью отработаны в течение трех десятилетий. Подробная характеристика строения и состава жил массива НКТ дана В.А. Маслениковым и П.В. Лялиным [22]. Сульфидные жилы вытянуты вдоль длинной оси массива и имеют простирание от меридионального до северо-восточного. Залегая почти вертикально, они не выходят за пределы массива и выклиниваются, не достигая его границ, как по простиранию, так и по падению. Длина жил от 100 до 1400 м, протяженность на глубину от 30 до 440 м, мощность от нескольких сантиметров до 2-3 м, обычная - 20-60 см. Жилы сложены сплошными сульфидными рудами, состоящими главным образом из пирротина, пентландита, халькопирита и магнетита.

В работе [22] указывается, что в направлении на юг по простиранию жил, в их составе появляются плагиоклаз, роговая обманка, биотит, апатит и сульфидные жилы переходят в жилы габбро-пегматитов, преобладающими минералами которых являются плагиоклаз и амфиболизированные пироксены. Выделяются участки меланократового пегматита и лейкократовые участки, почти нацело сложенные плагиоклазом. В северной и южной частях НКТ сульфидные жилы по простиранию переходят в магнетитовые. 


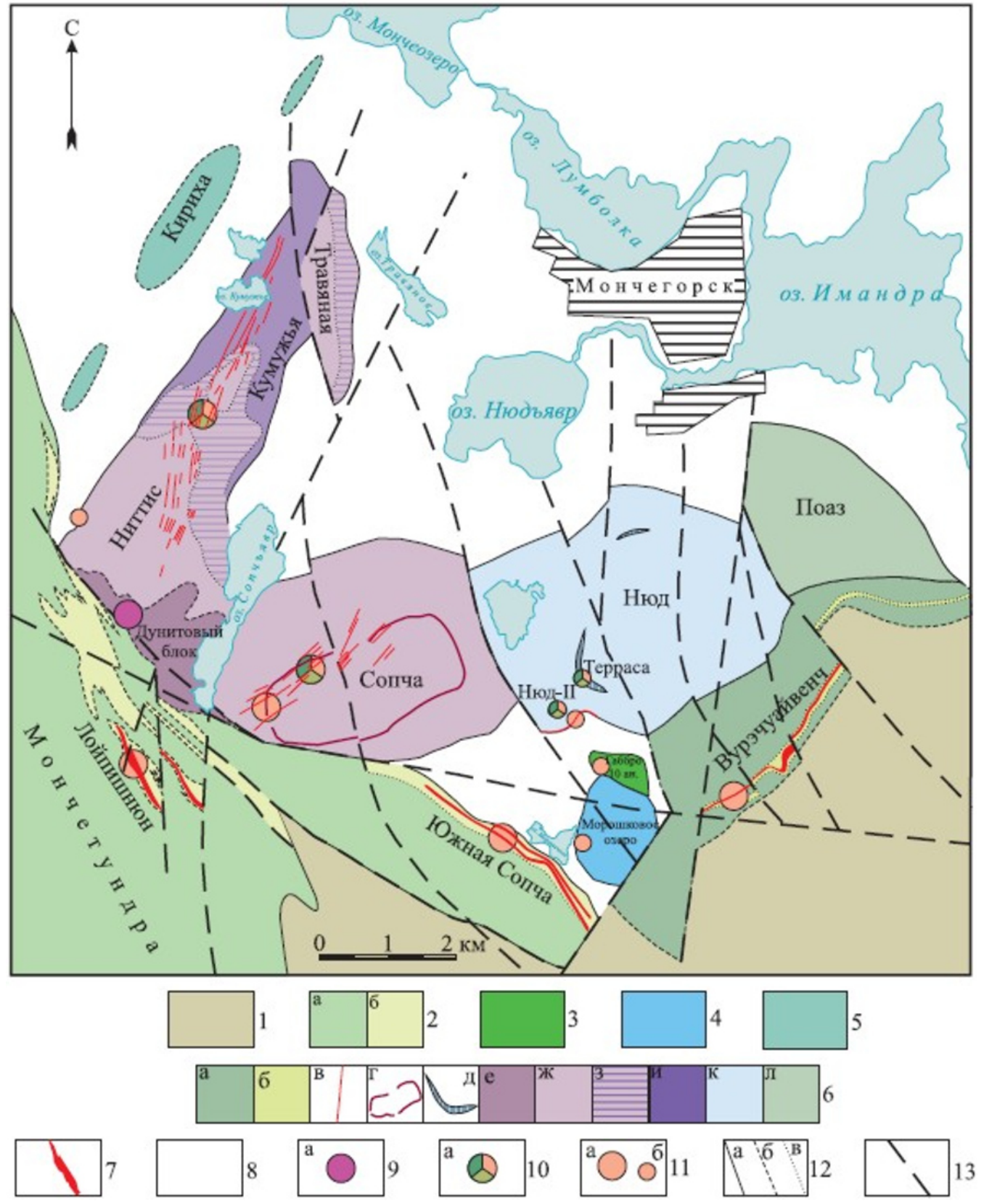

Puc. 2. Схема размещения месторождений и проявлений в пределах Мончеплутона и его обрамления [18]: 1 - ИмандраВарзугская рифтогенная структура; 2 - Мончетундровский массив: верхняя зона - метагаббро, метагаббронориты и анортозиты среднекрупнозернистые (а), нижняя зона - нориты и ортопироксениты мелкосреднезернистые (б); 3 - кварцевое метагаббро массива 10й аномалии; 4 - нориты лейкомезократовые массива Морошковое озеро; 5 - габбронориты массива Кириха; 6 - Мончеплутон: метагаббронориты (а) и плагиоклазиты (б) предгорий Вурэчуайвенч, сульфидные жилы (в), пласт 330го горизонта (г), «критический горизонт» (д), Дунитовый блок (е), ортопироксениты (ж), переслаивание ортопироксенитов и гарцбургитов (3), гарцбургиты (и), нориты (к), габбронориты (л); 7 - горизонты сульфидной платинометальной минерализации; 8 - архейские метаморфические и ультраметаморфические образования Кольского блока; 9-11 - месторождения (а) и проявления (б): 9 - хромовых руд, 10 - платиномедноникелевых руд, 11 - малосульфидных платинометальных руд; 12 - геологические границы: достоверные (а), предполагаемые (б), фациальные (в); 13 - разрывные нарушения.

В. А. Маслеников и П. В. Лялин пришли к выводу, что в участках, близких к корням интрузии НКТ, ультрабазиты пересекаются жилами норитов и габброноритов, которые севернее сменяются жильными породами типа габбро-пегматитов, а далее типичными крупнозернистыми пегматитами (последние по простиранию переходят в сульфидные жилы) [22].

Жильные сульфидные тела в массиве Сопча были обнаружены при бурении глубоких скважин. Они состоят из сульфидов, магнетита, а также из карбонатов, хлорита и актинолита. Дальнейшие исследования показали, что жильное поле горы Сопча сложено крутопадающими на юго-восток (80-90) жилами с простиранием $20-30^{\circ}$ в северо-восточной части и $50-60^{\circ}$ в юго-западной части. Жилы связаны с зонами повышенной трещиноватости и бластомилонитизации. 
Общий объем жильного оруденения в массиве Сопча значительно уступает таковому в НКТ. Мощность жил невелика, раздувы и гнезда основных пегматитов практически отсутствуют [19].

Рудные поля НКТ и Сопчи образуют веерообразно расходящийся от сочленения Мончеплутона с Мончетундровской интрузией пучок жил север-северовосточного простирания с азимутами от $0^{\circ}$ до $20^{\circ}$ в массиве НКТ и от $20^{\circ}$ до $50^{\circ}$ в массиве Сопча [19]. По мнению большинства исследователей, крутопадающие жилы сформировались на заключительных стадиях развития Мончегорского комплекса путем заполнения тектонических трещин, образовавшихся после затвердевания интрузии. Как уже говорилось выше, месторождения сплошных жильных руд к настоящему времени являются полностью отработанными. Однако внимание к новым рудным объектам Мончегорского комплекса, связанным с жилами различного состава и генезиса до сих пор не ослабевает.

Так, представляется важным обратить внимание на то, что жильная сульфидная и PGE минерализация НКТ была детально изучена в ходе относительно недавних работ в пределах участка Западный Ниттис. Помимо известной ранее магматической вкрапленной малосульфидной минерализации «донной залежи», здесь работами ОАО «Центрально-Кольская экспедиция» в 2012 году впервые установлена эпигенетическая минерализация, включающая в себя сульфидные жилы и прожилковые зоны, вкрапленную минерализацию и богатые сульфидами шлиры, значительная часть из которых содержит высокие и аномальные концентрации PGE ( $\pm \mathrm{Au})[23]$.

Рудная минерализация связана с двумя системами сульфидных жил. Первая (субвертикальная, перпендикулярная расслоенности) выполнена сульфидными жилами толщиной до 1-2 см, окруженными ореолами вторичных изменений пород. Жилы имеют невыдержанную мощность, неровные границы, иногда переходя в сульфидные шлиры (видимая мощность до 5 см), сульфидный материал жил обогащен PGE (до 110 кг/т). Вторая система формирует многочисленные тонкие жилы и прожилки с резкими границами, без существенных вторичных изменений. Минеральный состав жил представлен халькопиритом, второстепенные минералы - миллеритом, пентландитом и борнитом. Помимо этого, встречена богатая эпигенетическая платинометальная минерализация в дайке долеритов, секущей сульфидные жилы. В этих PGE-Cu жилах и дайке долеритов выявлено более 20 минералов PGE и золота [23].

Как уже упоминалось выше, многие дайковые тела локального комплекса, а также часть жил различного состава приурочены к зоне сочленения двух подразделений Мончегорского комплекса - Мончеплутона и Мончетундровской интрузии. Ее строение было детально изучено В.С. Докучаевой [24] в пределах так называемого «юго-западного приконтактового участка Мончегорского плутона», характеризующего придонную часть массива НКТ. Обобщенный разрез участка представлен зоной переслаивания пород основного и ультраосновного состава мощностью 150 300 м. В зоне наблюдается переслаивание пироксенитов и перидотитов, аналогичных породам Мончеплутона; габбро, аналогичных породам Главного хребта, а также габбро- и диорит-пегматитов. Среди пироксенитов встречены жильные габбро-пегматиты, диоритпегматиты и гранофиры. Контакты жильных пород с пироксенитами резкие, под разными углами к оси керна. Мощность жильных пород колеблется от 5- 8 см до 80-100 см, на отдельных глубинах они образуют густую сеть. В этом случае остроугольные обломки пироксенита сцементированы жильной породой, т.е. породу в целом можно назвать «эруптивной брекчией». Жилки пегматоидов в большинстве случаев имеют неоднородное сложение: их краевые части в контакте с пироксенитами состоят из темноцветных минералов, а в остальных частях жил преобладают полевой шпат и кварц [24].

Среди ультраосновных пород встречено большое количество участков габбро, в том числе жилы габбро-пегматита с рудной минерализацией. В габбропегматитах вкрапленники рудных минералов достигают размера 1-2 см в поперечнике. Они окружены ореолом тонкой рассеянной вкрапленности. Главными минералами являются магнетит, титаномагнетит, халькопирит, пирротин, меньшую роль играют пентландит, борнит, пирит, иногда встречаются миллерит и минералы платиноидов. Жилы габбрового и диоритового состава имеют широкое развитие на данном участке, но рудная вкрапленность встречается в них крайне неравномерно, без видимой закономерности [24]. Данное оруденение было отнесено к так называемому инъекционному, существенно никелевому типу. Несмотря на то, что в отдельных пробах содержания $\mathrm{Ni}$ в рудах может достигать $8 \%$, из-за сильной неравномерности в распределении рудной минерализации этот тип в отношении данного металла был признан промышленно неперспективным [18].

Жильные тела зоны сочленения Мончеплутона и Мончетундровской интрузии были детально исследованы в районе «южного приконтактового участка» (так называемый Южносопчинский массив, далее ЮСМ) сотрудниками Геологического института КНЦ РАН в 2010-2011 гг. По итогам работ было отмечено, что минеральный состав жил изменяется от преимущественно ортопироксенового до амфибол-плагиоклазового (рис. 3). Наиболее мощные жилы сложены черной на сколе крупнозернистой массивной породой, где хорошо видны крупные выделения магнетита и мелкая сульфидная вкрапленность, а в ряде случаев хромитовая минерализация [13].

Касаясь не никелевой, а PGE минерализации описываемого участка, крайне важно подчеркнуть, что развитие пироксенитовых жил в его пределах было известно с 70-х годов прошлого века. Так, еще на схематической геологической карте массива Нюд-Поаз, выполненной в Мурманской экспедиции в 1972 г. (ответственный исполнитель отчета $\mathrm{B}$. В. Шолохнев) в 


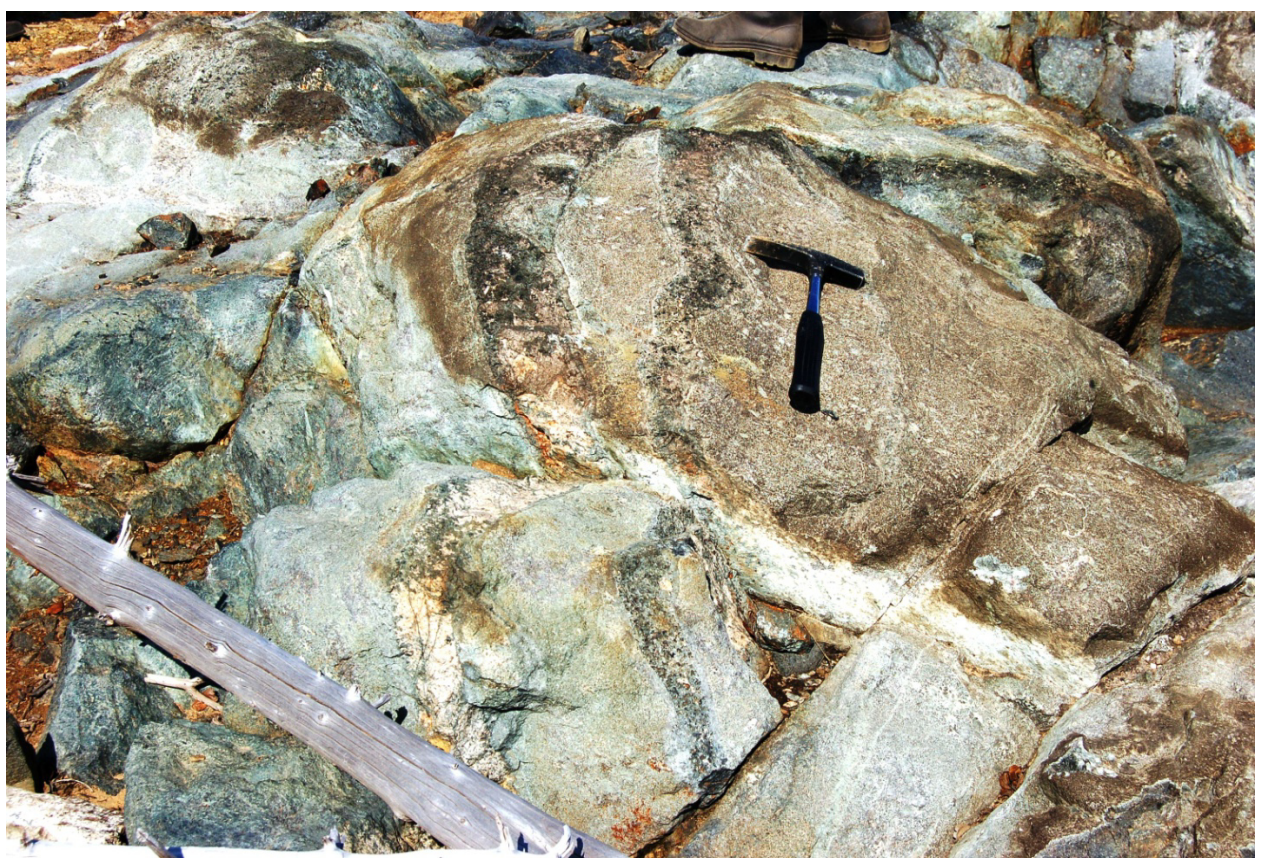

Puc. 3. «Расслоенность» в Южносопчинском массиве: система субпараллельных магнетит-плагиоклаз-амфиболовых жил в метапироксените. Амфибол развивается по пироксену.

пределах ЮСМ в качестве главного элемента неоднородности разреза были показаны именно пироксенитовые жилы. Однако в дальнейшем платинометальное оруденение, по нашему мнению, ошибочно было отнесено к «рифовому типу», приуроченному к зоне чередования «слоев» пироксенитов и норитов [17, 25]. В частности, нами было подчеркнуто, что в зоне сочленения Мончеплутона и Мончетундровской интрузии развита магматическая (интрузивная) брекчия, а связанное с жилами сульфидное и PGE оруденение, вероятно, относится не к рифовому, а контактному типу, переотложенному при позднемагматических процессах [13]. Следует заметить, что в работе [18] оруденение ЮСМ также отнесено не к «рифовому», а к «базальному типу», связанному с краевой серией. К сожалению, никакого упоминания про интенсивное брекчирование пород и существенную роль жил в перераспределении рудного вещества в этой работе не приводится (более того, на рис. 2 оруденение ЮСМ показано в виде горизонта, согласно легенде не отличающегося от рифа массива Вурэчуайвенч). Нашими исследованиями установлено, что повсеместно для всех типов жил отмечается присутствие магнетитовой и сульфидной вкрапленности, причем содержание магнетита и сульфидов варьирует от единичных зерен до 3 \% объема породы. Исследования также показали, что сульфидная и платинометальная минерализация связаны с жилами магнетит-плагиоклаз-пироксенового состава (рис. 3), залегающими в метапироксенитах [26, 27]. Хочется подчеркнуть, что эти рудные тела ЮСМ, вкупе с двумя рудопроявлениями «рифового типа» («пласт-330» массива Сопча и месторождение Вурэчуайвенч) входят в перспективную зону промышленной PGE минерализации Мончеплутона [28].

Таким образом, исследования 2011-2012 годов вновь обратили внимание геологов на потенциал различных жильных образований Мончегорского комплекса (главным образом - Мончеплутона). Очевидно, что при постановке дальнейших геологоразведочных работ необходимо учитывать перспективы сульфидной эпигенетической медно-платиновой минерализации (участок Западный Ниттис), а также переотложенного жилами плагиоклаз-пироксенового состава так называемого «контактного» PGE оруденения (зона сочленения Мончеплутона и Мончетундровской интрузии).

\section{Выводы}

С породами дайково-жильного комплекса в дифференцированных магматических комплексах связаны значительные, а в ряде случаев - главные типы промышленной $\mathrm{Cu}-\mathrm{Ni}-\mathrm{PGE}$ минерализации.

Локальный дайковый комплекс в пределах Мончегорских мафит-ультрамафитовых интрузий за единичными исключениями не несет существенной рудной минерализации.

Жильные породы (сплошные сульфидные жилы) на протяжении многих лет являлись главным промышленным типом $\mathrm{Cu}-\mathrm{Ni}$ ( \pm PGE) руд Мончеплутона. После их отработки, наиболее перспективным стал считаться малосульфидный «рифовый» тип PGE минерализации.

Однако как показывают исследования последних лет, перспективы разработки жильных руд для Мончегорского комплекса вновь являются актуальными. Причем, как собственно жильной эпигенетической сульфидной $\mathrm{Cu}-\mathrm{PGE}$ минерализации (участок Западный Ниттис), так и минерализации «контактного» типа с участием минерализованных жил зоны сочленения Мончеплутона и Мончетундровской интрузии (Южносопчинский массив). 


\section{ЛИТЕРАТУРА}

1. Чернышов, Н. М. Рудонесущая роль даек сульфидных платиноидно-медно-никелевых рудно-магматических систем / Н. М. Чернышов, М. Н. Чернышова // Вестн. Воронеж. гос. унта. Сер.: Геология. -2008. - № 2. - С. 109-132.

2. Налдретт, А. Дж. Магматические сульфидные месторождения медно-никелевых и платинометалльных руд / А. Дж. Налдретт. - СПб. : СПбГУ. - 2003. - 487 с.

3. Naldrett A. J. Ultramafic and related mafic rocks: their classification and genesis with special reference to the concentration of nickel sulfides and platinum-group elements / A. J. Naldrett, L. J. Cabri // Econ. Geol. - 1976. - V. 71. - P. 1131-1158.

4. Кислов, Е. В. Новые данные по петрологии и рудообразованию платинометально-медно-никелевого месторождения Джиньчуань (Ганьсу, Китай) / Е. В. Кислов // Минерагения СевероВосточной Азии. - Улан-Удэ : ИД «Экос». - 2011. - С. 71-74.

5. James, R. S. Geology and petrogenesis of the Kanichee layered complex, Ontario. / R. S. James, D. Hawke // Canadian Mineralogist. - 1984. -V.22. - P. 93-109.

6. Mutanen, T. The Akanvaara intrusion and the Keivitsa - Satovaara Complex, with stops at Kaikkivaltiaanlehto and Rantavaara intrusions / T. Mutanen // Field trip Guidebook By Tapani Mutanen prepared for the 10 th Platinum Symposium in Oulu, Finland 2005. Geological Survey of Finland, ESPOO. - 2005. - 124 p.

7. Последовательность минералообразования в сульфидноплатинометальных рудах в косьвитах Кондёрского массива / С. В. Петров [и др.] // Проблемы геологии и эксплуатации месторождений платиновых металлов (I научные чтения памяти проф. В. Г. Лазаренкова) : Материалы Всероссийской конференции с международным участием (Санкт- Петербург, 25 мая 2016 г) Горный университет - СПб. Изд-во СПГУ. - 2016. - С. 16-22.

8. Телегин, Ю. М. Некоторые особенности платиноносных минерализованных зон Светлоборского пироксенит-дунитового массива (Средний Урал) / Ю. М. Телегин // Проблемы геологии и эксплуатации месторождений платиновых металлов (I научные чтения памяти проф. В.Г. Лазаренкова) : Материалы Всероссийской конференции с международным участием (СанктПетербург, 25 мая 2016 г) Горный университет - СПб. Изд-во СПГУ. - 2016. - С. 53-57.

9. Xin, Ding. PGE geochemistry of the Eagle Ni-Cu-(PGE) deposit, Upper Michigan : constraints on ore genesis in a dynamic magma conduit / Ding Xin, M. Ripley Edward, Li Chusi // Mineralium Deposita. - 2012. - V 47. - Issue 1-2. - P. 89-104.

10. Critical controls on the formation of contact-style PGE-Ni-Cu mineralization : Evidence from the Paleoproterozoic Monchegorsk Complex, NW Russia / B. T. Karykowski [et al.] // Conference Proceedings (PDFs of abstracts and oral and poster presentations) from SEG 2017: Ore Deposits of Asia: China and Beyond held in Beijing, China [Электронный pecypc]. URL: https://www.seg web.org/SEG/Events/Conference_Archives/2017/Conference_Proce edings/files/pdf/Oral-Presentations/Abstracts/Karykowski.pdf (Дата обращения 01.03.2018).

11. Zientek, M. L. Magmatic ore deposits in layered intrusionsDescriptive model for reef-type PGE and contact-type Cu-Ni-PGE deposits / M. L. Zientek // U.S. Geological Survey Open-File Report 2012-1010. -2012. $-48 \mathrm{p}$.

12. Iljina M.J. PGE deposits in the marginal series of layered intrusions / M. J. Iljina, C. A Lee // Mineralogical Association of Canada Short Course 35, Oulu, Finland. - 2005. - P. 75-96

13. Geological structure and ore mineralization of the South Sopchinsky and Gabbro-10 massifs and the Moroshkovoe Lake target, Monchegorsk area, Kola Peninsula, Russia / P. V. Pripachkin [et al.] // Mineralium Deposita. - 2016. V.51. - N 8. -P. 973-992.

14. Basal Platinum-Group Element Mineralization in the Fedorov

Геологический институт Кольского научного иентра РАН (ГИ КНЦ РАН), Апатить. Припачкин Павел Валентинович, к. г.-м. н., старший научный сотрудник

E-mail: paul@geoksc.apatity.ru; Teл. +7-81555-79-288
Pansky Layered Mafic Intrusion, Kola Peninsula, Russia / D. Schissel [et al.] // Economic Geology. - 2002. - Vol. 97. - P. 1657-1677.

15. Грошев, Н. Ю. Двухфазный платиноносный массив Федоровой тундры (Кольский полуостров) : геология и типы малосульфидного ЭПГ-оруденения / Н. Ю. Грошев // Автор. Канд. Дисс. Апатиты. $-2010 .-24$ c.

16. Шарков, Е. В. Формирование расслоенных интрузивов и связанного с ними оруденения / Е. В. Шарков // М. : Научный Мир. - 2006. - 368 с.

17. Геологическое строение, минералогия и генезис ЭПГминерализации массива Южная Сопча, Мончегорский комплекс, Россия / Т. Л. Гроховская [и др.] // Геология рудных месторождений. - 2012. - Т. 54. - № 5. - С. 416-440.

18. Чащии, В. В. Палеопротерозойская Имандра-Варзугская рифтогенная структура (Кольский полуостров) : интрузивный магматизм и минерагения / В. В. Чащин, Ф. П. Митрофанов // Геодинамика и тектонофизика. - 2014. - № 5. - Т.1. - С. 231-256 19. Расслоенные интрузии Мончегорского рудного района : петрология, оруденение, изотопия, глубинное строение / Под ред. Ф. П. Митрофанова, В. Ф. Смолькина. Часть 1. Апатиты: Изд-во КНЦ РАН. - 2004. - 177 с.

20. Арзамасиев, А. А. Дайковый магматизм северо-восточной части Балтийского щита / А. А. Арзамасцев, Ж. А. Федотов, Л. В. Арзамасцева // СПб. : Наука. - 2009. - 383 с.

21. Козлов, Е. К. Естественные ряды пород никеленосных интрузий и их металлогения / Е. К. Козлов // Л. : Наука. 1973. -288 c.

22. Геология и рудные месторождения Мончегорского плутона. Труды ЛАГЕД АН СССР, Выпуск 3, Л. : Изд-во АН СССР. 1956. $-328 \mathrm{c}$.

23. Особенности распределения минералов благородных металлов в медно-платиновых жилах участка Западный Ниттис Мончегорского расслоенного плутона (Кольский п-ов) / О. В. Казанов [и др.] // Проблемы геологии и эксплуатации месторождений платиновых металлов (I научные чтения памяти проф. В. Г. Лазаренкова) : Материалы Всероссийской конференции с международным участием (Санкт- Петербург, 25 мая 2016 г) Горный университет - СПб. Изд-во СПГУ. - 2016. - С. 62-66.

24. Докучаева, В. С. Геология и петрография придонной части массива Ниттис-Кумужья-Травяная / В.С. Докучаева // Окончательный научный отчет. Апатиты, Фонды КНЦ РАН. 1960. -484 c.

25. Информационный отчет о результатах поисковых работ на металлы платиновой группы в Мончегорском районе (Мончегорский и Мончетундровский массивы) в 1999-2002 гг. / В. С. Войтехович [и др.] - Мончегорск, ОАО «ЦКЭ». - 2002. - Книга 1. $236 \mathrm{c}$.

26. Геологическое строение и особенности локализации платинометального оруденения в восточной части Южносопчинского мафит-ультрамафитового массива (Кольский полуостров) / Т. В. Рундквист [и др.] // Руды и металлы. - 2011. - № 5. - С. 58-68.

27. Рундквист, Т. В. Особенности взаимоотношений интрузивных тел в зоне контакта ультрамафит-мафитовых комплексов Мончегорский и Главного хребта (участок «Южносопчинский», Кольский полуостров) / Т. В. Рундквист, П. В. Припачкин, Р. А. Гребнев // Литосфера. - 2012. - № 3. - С. 65-79.

28. Иванченко, В. Н. Основные черты геологического строения месторождений и проявлений МПГ южной части Мончегорского рудного района / В.Н. Иванченко, П. С. Давыдов // Проект Интеррег-Тасис : Стратегические минеральные ресурсы Лапландии - основа устойчивого развития Севера. Сборник материалов проекта. Вып. ІІ. Апатиты: КНЦ РАН. - 2009. - С. $70-78$.

Geological Institute of the Kola Science Center of the Russian Academy of Sciences (GI KSC RAS), Apatity

Pripachkin P. V., the PhD of Geological and Mineralogical sciences, senior researcher. E-mail: paul@geoksc.apatity.ru 